\title{
LEGAL REQUIREMENTS THAT BUILDING CONTRACTORS BE LICENSED*
}

\author{
Corwin D. Edwards $\dagger$
}

The various statutes requiring the licensing of building contractors by states and municipalities during the last few years purport to express the public interest. ${ }^{2}$ Such laws are said by their advocates to be necessary in order to protect the general public against various abuses. The purpose of this memorandum is to provide a basis for appraisal of this assertion by examining the content of such statutes and the way in which they are actually used.

Ordinarily when abuses within an industry or trade have become so prevalent that they require extensive public control, the persons who point out the evil are those who must deal with the industry as customers or as employees, not the business enterprises within the industry itself. Ordinarily, too, a large majority of the concerns engaged in an industry look with dislike and suspicion upon governmental action designed to limit their freedom to do business as they see fit. Hence the general pattern in extending the use of governmental police power over business is demand by outside groups and resistance by the industry. . No type of government regulation is generally thought of by business men as more objectionable than a licensing provision under which the right to enter or continue in an industry becomes subject to governmental approval.

Proposals that contractors be licensed have been conspicuous exceptions to this general rule. The advocates of contractor licensing have been organized groups of persons who would be subject to the proposed licenses. Where such laws have been opposed, the opposition has usually come from outside the group to be controlled.

\footnotetext{
- This paper was prepared by the author at the request of the National Electrical Manufacturcrs' Association and is published in this symposium by permission of the Association; it does not necessarily reflect the views of the Association.-[Editor]

† A.B., 1920, B.J., 1921, University of Missouri; B.Litt., 1924, Oxford University; Ph.D., 1928, Cornell University. Professor of Economics, Northwestern University. Chairman of the Conference on Price Research, National Bureau of Economic Research. Formerly head of American Mission on Japanese Combines, 1946; Chief of Staff, American Technical Mission to Brazil, 1942-43. At various times: consultant on cartels, U. S. Department of State; Chairman of Policy Board, Anti-Trust Division, Department of Justice; Assistant Chief Economist, Federal Trade Commission; Technical Director, Consumers Advisory Board, NRA. Member, Executive Committee, American Economic Association, 1943-45. Author, Economic and Political Aspects of International Cartels 1944; co-author, A Cartel Policy for the United Nations (1945); Economic Problems in a Changing World (1939); Economic Behaviok (1933). Contributor to economic periodicals.

${ }^{1}$ In the construction industry laws requiring that contractors be licensed are relatively new but show signs of spreading rapidly. I am not qualified to say how far the issues which they create in the building field may be like those which arise in the licensing of barbers, beauty shops, and similar establishments, where licensing requirements are well established.
} 
This demand to be regulated is not unique, though it is exceptional. There have been other cases in which members of the industry subjected to regulation have been advocates of the scheme. The most conspicuous instance is that of NRA, under which the industrial codes were regarded as desirable by many trade groups, in spite of the fact that through these codes detailed controls over marketing practices were established.

In NRA and similar cases in which trade groups have bcen hospitable to regulation, the members of the regulated industry have generally believed that the central purpose of the proposed controls was to enhance the industry's prices and profits, and that administration would be left either to key members of the industry or to outsiders who would be sympathetic to the industry's interests and attitudes. It is noteworthy that in the latter days of NRA the business support for code programs of trade practice control was greatly diminished because it had become clear that the government must take over an increasingly large share of responsibility for both policy and administration. With such analogies in mind, the attitude of contractors toward contractor licensing necessarily raises the question whether they too do not find in such a program legislative support for their own trade rather than a protection of the public interest.

In particular instances it is clear that trade interests, narrowly conceived, have furnished the incentive for the licensing of contractors. Let us examine the ways in which a licensing system may bolster the position of a particular group of contractors.

I. Licensing may be used to limit the total number of persons who sell contracting service and thus to reduce the intensity of their competition with one another. Ordinarily it is not possible to use a licensing system to drive out of the industry people who are already well-established in it. An attempt to do so would bring about disputes which might jeopardize the adoption of the system. However, licenses are readily used to limit the industry to its present size or to reduce the rate of its expansion by discrimination against newcomers. The point was clearly put in the 1938 Convention of the Tile and Mantel Contractors' Association of America in an explanation of the North Carolina Tile Contractors' Licensing Law. "All persons who were engaged in title contracting on the Ist of March, 1937, in the state, who furnished proper proof, received licenses. That was necessary to be done. You can't put anyone out of business already in the business. We can control the future, but we cannot control the past."3

Using this principle the North Carolina tile contractors froze the tile contracting industry of the state at the number already engaged in it. "We have in the state

${ }^{2}$ N. C. Gen. Stats. (1943) $\$ 87-28$ et seq. Because of the unusual candor of the discussion at this meeting of the Association, the North Carolina tile law is used throughout this article as a convenient illustration of the forces at work in contractor licensing.

"Tile and Mantel Contractors' Ass'n, Convention Proceedings (mecting held at Atlanta, Ga, Feb. 8-10, 1938) 8r. Hereinafter cited as "ProcenediNes." 
thirty-nine licensed tile contractors and those contractors were engaged in business prior to the time that this Act went into effect in March, 1937. I would say that since that date we have had no additional contractors in the state. ... Every contractor who was doing business in North Carolina prior to the enactment of the law and at the time of its enactment has secured a license and received that license without examination. We have conducted two examinations, and the applicants for license were nor qualified to do business, either by reason of their lack of education or other qualifications to engage in such business."

A restriction of the number of persons in an industry is in effect an indirect restriction of output. It automatically limits the maximum output to that which can be supplied by the operation of these persons at their full capacity and by such expansion of their capacity as they may undertake. In practice the established members of an industry are unlikely to expand their capacity, except when their business is highly profitable, whereas newcomers may appear for various other reasons, such as the desire to achieve business independence, the hope of introducing more economical business methods, and even the effort to earn something by self-employment when paid jobs are not available. Provided they think other established firms will do likewise, the established members of an industry are likely to limit their production to less than their capacity for fear of spoiling the market price, so long as they know that outside competition is not to be feared. Such restrictive understandings are facilitated where the established concerns are bound together in informal acceptance of conventional ways of doing things; for these conventions frequently include common ideas as to how prices should be computed, what are appropriate percentages of profit, and how far part-time operation should be preferred to price-cutting. The force of such common ideas is greatly enhanced by any measures which exclude newcomers who may have different opinions.

2. Licensing may be used to exclude business enterprises which are unorthodox in their methods of organization or their ways of doing business. Among building contractors the groups thus excluded are of several different kinds.

a. General contractors. Sometimes a general contractor chooses not to subcontract different parts of a building operation but rather to supervise the performance of these parts himself. This departure from the customary system of contracts and subcontracts is bitterly resented by enterprises which specialize in subcontracting. Licensing can be used to prevent such departures. In North Carolina "a number of general contractors, for instance, employed tile setters and mechanics to do their tile work; those people were not qualified to receive license under the law; all of that has been stopped...."

b. Other groups of subcontractors. The various operations of building construction have been conventionally subdivided into various fields, each of which lies within the jurisdiction of a particular type of subcontractor. The skill necessary to perform one subcontracting operation is sometimes not greatly different from that

Id. at 86.

Ibid. 
used in another such operation. Moreover, as building techniques develop and substitute building materials appear, contracting groups tend to undertake new types of work to replace operations which are diminishing in importance. They are particularly likely to compete with each other for types of work which do not clearly fall within any one of the older fields.

A subcontracting group which finds its jurisdictional claims disregarded by another may invoke a license law to establish and perpetuate its own ideas of jurisdiction. This too was one of the purposes of the tile contractors' licensing systems in North Carolina. ". . . we had a number of evils. The brick mason who was out of work was soliciting business of every type. He naturally solicited a certain amount of tile business. The plasterer followed suit, as did the linoleum layer . . . the brick mason cannot qualify under this licensing law and has stopped attempting the installation of tile work and gone back to his trade of laying brick; the plasterdr has followed suit and the linoleum layer."

Similarly, a Pennsylvania licensing law has been used to protect plumbers against the incursions of other contracting groups. Under this statute only registered master plumbers and registered journeymen in their employ are allowed to make connections with water pipes. An electrical contractor was prosecuted under the statute for connecting an electric heater to water pipes in a residence. ${ }^{7}$

c. The self-employed journeyman. Subcontracting operations are often very small. Indeed, a particular job frequently requires no more than a journeyman and a helper. The skill required in laying out the job can be picked up by an intelligent workman. Relatively little capital is required for small operations. Ambitious journeymen constantly attempt to go into business for themselves as contractors. When business is bad and journeymen are unemployed, they are likely to seek contracts rather than remain idle. The self-employed contractor presents a problem to the building trades unions and to contractors who employ union labor, because his hours of work and his compensation for a day's labor may be inferior to the union standard. But even where he observes union conditions, he is a problem to the established contractor because he avoids some of the established concern's costs and because, since he makes his living partly or wholly from work on the job, he does not need to make it exclusively from his contracting profits.

This type of problem is likely to be peculiarly-important in the years immediately after the war. It seems probable that many ex-servicemen will take advantage of government assistance to start small businesses for themselves, and that many of - them, particularly those with Seabee experience, will be qualified to plan and execute construction jobs. The interests of established construction subcontractors will thus be arrayed against those of a considerable number of men who wish to return to civilian life as self-employed subcontractors.

Licensing laws are used as obstacles to such self-employment. Once more the tilemen's observations on North Carolina tile law furnish an example. "The un-

\footnotetext{
'Id. 2t 83. 'Commonwealth v. Leswing, 135 Pa. Super. 485, 5 A. (2d) 809 (1939).
} 
employment situation caused the tile setters, a considerable portion of them still apprentice boys, to take a bucket, a few tools, an old automobile, and a few samples they had probably taken out of the backend of some legitimate tile contractor's shop, and set out to solicit tile business . . . it is a legitimate tile contractor who pays the burden of taxation, while the fly-by-night contractor, or the curbstoner, pays little, if any, part of the proper burden of taxation, and only through this law have we been able to bring out in North Carolina all the tile contracting in the state, and make it subject to the same rights and regulations that govern the business in general....."

Various devices are used to deny the self-employed journeyman a license. Sometimes this is accomplished through discriminatory administration of a licensing law. In other cases, however, the wording of the statute is designed to require the withholding of the license from persons who carry on business from their homes because they do not do business upon a substantial scale. The Pennsylvania law about plumbing, for example, provides that: "Every registered master plumber shall have a bona fide place of business ... and shall display on the front of his or their place of business a sign, 'Registered Plumber,' bearing the name or names of the person, firm, or corporation, in letters not less than three inches high."

d. Owners of property under construction. In some cases the person who owns a building which needs alteration or repair, or who is to own a building under construction, does not feel the need for the services of a contractor. The owner may have had experience in the construction industry or may have in his employment an architect, engineer, or other person whose experience he regards as adequate. The work to be done may be simple. Under such circumstances an owner may buy construction materials, employ construction labor, and supply the managerial direction himself. This type of arrangement is sometimes made by a householder in minor work upon his own residence and sometimes by an investment builder who undertakes a certain kind of building operation over and over again. In either case the independent contractor is likely to resent what he regards as invasion of his legitimate market.

Contracting laws are used to break up such practices. In North Carolina, "we have had this situation arise from time to time-an owner would buy tile, order through some jobber or have it shipped directly to him, and he would employ a brick layer or a tile setter, to set that tile, and then, in the enforcement of the Act, we would go to him, he would say: 'I am not engaged in tile contracting at all, this man is working for me, by the hour, or by the day; he is not a contractor, and you can't stop us.' . . . Under the wording of this Act, I am glad to be able to say that we have made it applicable to, and have been fortunate enough to stop jobs of that nature. ... We have had to issue warrants in several cases, but we. have been successful so far in all of our endeavors. . .."10

\footnotetext{
- Proceedings, supra note 3 2t 82, 83 .

- Pa. Stat. Ann. (Purdon, Cum. Supp. 1944) tit. 53, 32554.

${ }^{10}$ Proceedings, supra note 3 , at $8 x, 85$.
} 
This type of attack was extended to cover the investment builder:

"Mr. Martin: I suppose you are infected with the investment builder whose procedure is to hire some mechanic to buy the tile through a manufacturer or jobber. The investment builder is building the house in his name, preparing to sell it, naturally, and he goes with the tile mechanic or workman to buy and pay for the tile; he buys the building material that is on the job, and then this man can prove that the only thing that the investment builder has paid him for is the wages; in that instance do you attack bothquestion the investment builder's right as a tile contractor, or do you also prefer charges against the mechanic who is operating against the system?

"Mr. CARTER: We prefer charges in such instances against both parties. . . .

"Mr. Martin: Do you think it is effective in stopping the practice?

"Mr. CarTer: We have stopped it."11

3. Licensing laws are also used by the building contractors of a particular locality to keep the local market for themselves by excluding enterprises from other localities. In this way the licensing law becomes a legal device to counteract the technological forces which have been gradually destroying the isolated localism of building operations.

The clearest instances of efforts to discriminate between local and non-local contractors have to do with localities within a given state. The discriminations by state law against residents in other states are more indirect, so that they are likely to be matters of inference or of interpretation rather than of obvious fact. Presumably this difference between intra-state and inter-state arrangements is due to the fact that the Federal constitution is a substantial obstacle to discrimination by any state against the citizens of another, whereas the various state constitutions are often less adequate as safeguards of the equal treatment of the citizens of the state.

A striking case of local preference was summarized in a speech which I made in I940 as economic consultant to the Department of Justice: "Here is a copy of an ordinance passed in 1939 by a Pennsylvania city. It provides that all resident plumbers must pay a fee of $\$$ r.00 a fixture for each installation. Every non-resident plumber desiring to work in this city must register with the Board of Health for each and every job to be performed in the city, and must pay a registration fee as follows:

"Plumbing for each apartment of an apartment building, \$25.00.

"Plumbing for toilet room in any store room or store building, $\$ 25.00$.

"Plumbing for a double house, $\$ 50.00$.

"The fee for a resident in that city was $\$$ r.00 per fixture and the fee for nonresident was $\$ 1.00$ plus $\$ 25.00$ or more. An organization which sold plumbing equipment in this city happened to be large enough to hire its attorneys by the year, and decided to bring this fee system before a court. Thereupon the discriminatory fees were repealed. When people confronted by such a rule cannot afford legal expenses, ordinances of this sort do not get challenged, but continue to limit competition."12

12 Id. at 88.

${ }^{12}$ Corwin D. Edwards, Restraints in Building Codes, Centrar Housing Discusaon Papers: G: 1940 SERTES, pp. 4-5. 
The Pennsylvania state law which governs the licensing of plumbers appears to be designed to handicap the contractor who attempts to do business in a number of different localities, although the technique of discrimination is much less flagrant. This statute appears to discriminate against out-of-state contractors by requiring that every registered master plumber shall have a bona fide place of business in the locality where he is registered. Less obviously, it handicaps non-local plumbers resident within the state; a plumber registered in one locality is required to register in each other locality in which he takes business, although examination is waived for these additional registrations. Moreover, since each such registration is limited to the work which has been contracted for at the time registration takes place, the acceptance of a series of jobs in a city other than the contractor's place of residence requires a series of separate registrations in that city. ${ }^{13}$

The Illinois plumbing license law probably makes it difficult for any contractor to take plumbing jobs in any city in which he is not continuously engaged in business. Section $2 \mathrm{~F}$ provides that anyone who engages in the plumbing business "with sites or places of business in different cities of this state, shall have at least one licensed Master Plumber, as provided in this Act, continually in charge and supervision in each city where a site or place of plumbing business is so operated."14 If in the eyes of the law a plumbing contractor has a "place of plumbing business" in any city in which he takes a plumbing job, the meaning of this provision is that a master plumber, that is, an executive of the contracting firm, must be maintained continuously within the city, even though the plumbing jobs undertaken within the city by the contracting organization are intermittent in character. If this interpretation is correct, the natural effect of the statute is to exclude outside firms from competing for jobs.

The Arizona law which requires the licensing of all types of building contractors provides that before obtaining a license the applicant must submit a certificate signed by two reputable citizens of the county in which he resides, stating that he is of good reputation. The licensing authority is also required to determine that the applicant has had experience in the type of work he proposes to contract. These features of the statute interpose a certain natural handicap against out-of-state applicants. If the applicant is a corporation, it must show that it has qualified to do business "by completing all of the acts required for such qualification in this state and in each county in which the contract of any part thereof is to be performed."15

There are some indications that the North Carolina tile contractors' licensing law is also used against out-of-state contractors. On the one hand, the attorney who explained the law to the tile contractors' convention pointed out that "it was necessary that the law have uniform application without discrimination as to resident or non-resident contractors." 18 On the other hand, however, he found it necessary to admit to the convention that "the Board has been subjected to some criticism in the

\footnotetext{
${ }^{28}$ PA. Stat. ANw. (Purdon, Cum. Supp. 1944) tit. 53, \$52554, 2558.

14 InL. Stat. Awn. (Jones, 1944) Jioz.xiF. 18 ARIz. CoDe ANN. (1939) 567-805.

16 Proceedings, supta note 3 , at 80 .
} 
past by contractors of other states who have charged the Board with formulating a policy under which was attempted to keep non-resident contractors from doing business in North Carolina." This charge he denied. ${ }^{17}$ In subsequent discussion the following exchange took place:

"Mr. Alexander: Mr. Carter, as I understand the law, that is an outsider from without the state would have to qualify under your law before he bids on a job?

"Mr. CarTer: That is correct, sir; you have to qualify and get your license from the licensing board of the contractors-but if you don't come into the state of North Carolina we would have a difficult time prosecuting you."18

4. Licensing laws sometimes provide convenient devices with which to limit the intensity of competition. Since such endeavors are in danger of attack under the antitrust laws, they are often not explicitly avowed. Nevertheless, their character may be inferred from avowals like the following by a spokesman for the North Carolina tile contractors:

"This Association, like all of us, was faced with an impossible proposition of recruiting into its ranks all of the contractors in the state, even if it were willing to accept in its membership a large number of persons who held themselves out to the public as being tile contractors, and realizing at the outset that if any rule or set of regulations to be observed were to be adhered to only under a gentleman's agreement, and the only guarantee of the keeping of the rules and regulations being the words of the parties involved, then such a plan was of necessity foredoomed to failure.

"There seemed nothing left to the Association but to attempt to seek some form of control whereby a penalty might be imposed upon those persons who were not willing to adhere to the ethics of good business, and out of that grew the North Carolina Licensing: L2w."10

5. Licensing laws are used to prevent building materials from being distributed through unorthodox channels of distribution. In several of the building trades it is traditional for the building contractor to act also as the retailer of building materials and to sell these materials only in conjunction with the service of installing them in a building. This system makes it impossible for the owner of the building to obtain a clear-cut competitive comparison of retail prices for such building materials, or of contractors' charges for installation. An owner who wishes a particular brand of material is automatically prevented from employing as a contractor anyone who is not a dealer in that brand. An owner who wishes a particular contractor to serve him is automatically required to accept one of the brands which that contractor is able and willing to buy. An owner who wishes to install building materials without employing a contractor is prevented from doing so. A manufacturer is automatically excluded from the portion of the building market which is served by contractors. who do not handle his brands, and is given an automatic preference in that portion of the market served by contractors who prefer to handle his brands. If manufacturers use exclusive dealers and there are relatively few contractors in a local building market, manufacturers who cannot find contractors as dealers may be excluded from
${ }^{28} 18$. at 82.
${ }^{18}$ ld. at 86.
18. 12 . at 80. 
that local market entirely so long as their products cannot be sold there except on an installed basis. In so far as such a plan is effective, the maintenance of price controls or other restrictive practices by groups of contractors is greatly facilitated.

In the plumbing industry, proceedings were initiated a few years ago under the antitrust laws ${ }^{20}$ in which it was charged that master plumbers associations and the plumbers unions, with the aid of certain manufacturers, endeavored to enforce an orthodox system of distribution of this type. The concerns against which the effort was directed were certain other plumbing manufacturers and certain mail-order houses and other "direct to you" distributors through whom plumbing fixtures could be bought by hotels, factories, and other consuming establishments without the requirement that a contracting service be bought at the same time. ${ }^{21}$

Licensing laws have been used to reenforce this type of restriction upon plumbing. An example, which I described in a public speech in 1940 , is as follows:

"An apparently innocent provision of many codes is that plumbing should be done by licensed plumbers. The interpretation of the term 'plumbing' has been heavily influenced by pressure from master plumbers who desire that it include the advertising and selling of plumbing equipment. According to this rule, if I sell a tub I am a plumber. One such provision I obtained from a copy of a letter sent to a local plumbing company: 'No person other than a registered master plumber as herein provided, shall be allowed to carry on or engage in the business; nor shall any person or persons expose the sign of a plumbing house or building drainage or any advertisement or display pertaining thereto (wholesale show rooms excepted) unless he or they have first secured a license or certificate and been registered in the office of the Board or Bureau of Health of such cities.' "22

This provision, which is taken from the Pennsylvania law, ${ }^{23}$ was used in at least one Pennsylvania city in an effort to prevent a mail-order house from selling plumbing fixtures. A local building official called upon the manager of one of the retail outlets of the mail-order company to inquire whether, as he alleged was necessary to conform to the law, one of the chief executives of the mail-order company was a licensed plumber. After the mail-order house had shown willingness to test this interpretation of the law in the courts the local official lost interest in the case. This reluctance to invoke a judicial test may have been due to the fact that some years previously the courts had refused to sustain an effort to impose a less drastic restriction. There was an attempt to prevent employees of a company which sold hot water tanks from installing these tanks where the employee who made the installation was not a registered plumber. However, a Pennsylvania court held that this practice is not in violation of the law. 24

The North Carolina licensing law is used to reenforce the orthodox system of distributing tile through contractors. The first step in the process is to bring pres-

${ }^{20}$ United States v. Central Supply Assoc., et al., indictment in the Northern District of Ohio, March 29, 1940.

21 The indictment was upheld, against demurrers and motions to quash, even as against the labor unions and their officers. United States v. Central Supply Ass'n, 40 F. Supp. 964 (1941).

"Edwards, supra note 12, at 4 .

28 PA. Stat. Ans. (Purdon, Cum. Supp. 1944) tit. 53, $\$ 2555$.

* Commonwealth v. Noll, 33 Lack. 103 (1932). 
sure to bear upon manufacturers to sell only to licensed contractors, on the theory that otherwise they become accessories to a crime. "The majority of the tile manufacturers have cooperated very nicely with us in that they have refused to sell tile to other than licensed contractors.... Any manufacturer has a right to sell tile to anyone who buys it, and he cannot be stopped at all. We only request them, in view of the fact that we have this law, that they cooperate with us to such an extent that they sell to licensed contractors because when they sell to a brick layer or someone who they know is not qualified under the laws of the state to do business, they are in reality not following, I think, the practice of good business, because they are indirectly creating or becoming a party to a crime that will be committed."25

The second step is to attempt to prevent contractors in other states from selling tile in North Carolina. "The greatest number of the violations of our law have grown out of the bootlegging of tile ... tile contractors in other states will ship tile in to general contractors, or in to brick masons, and get the tile that way, and from those the violations of the law grow."2B

This type of practice is attacked upon the same theory that to sell to unlicensed tile contractors is to act as accessory to a crime. The theory would also be applied, if necessary, to the tile jobber, whose exclusion, though not of practical importance in North Carolina, is the third step in protecting established distributive channels: ${ }^{27}$

"Mr. McClamroch: ... we have no evil such as you have-we don't have jobbers. (Applause) We don't know of any jobbers that are shipping tile into North Carolina.... But if he does ship tile in to somebody who is not licensed he has become an accessory to the crime, the same as the manufacturer as we explained to you.

"Mr. PAPpalardo: I think that is nice."28

6. As the previous discussion should have made evident, licensing laws may be used to play favorites among persons who are or wish to be contractors. The most obvious and general form of favoritism is the preference for persons already engaged in the business as against newcomers. This preference is inherent in the procedure by which at the time a licensing law is enacted persons already established in the business are presumed to be competent and are given licenses without examination, whereas thereafter all applicants are subjected to examination.

Another type of favoritism may appear, however, in the administration of an established licensing system. The typical licensing law gives to officials chosen from contracting groups. wide discretion to determine the character of the examination which precedes the granting of a license and to grade the examination papers of applicants. There is typically no provision in the licensing law or in the procedure established under it to protect the applicant against discrimination. Opportunity is thus afforded for industry-minded inspectors to take into account, as qualifications

\footnotetext{
${ }^{28}$ Procirdings, supra note 3, at 85 .

"In the tile industry the contractors' associations have been concerned about the development of tile jobbers who carry a considerable stock of tile bought from various manufacturers and stand ready to sell this tile to the ultimate consumet and to contractors not engaged primarily in the tile business.

10. Id. 28.86.
} 
to engage in the business, such matters as the extent to which the applicant has engaged in or is likely to engage in sharp price competition, whether the applicant is persona grata to the trade union which has jurisdiction in his field, whether the applicant resides outside the state, and whether it is thought desirable by the established contractors to admit additional competitors into their occupation. As has already been pointed out, in the first year of the North Carolina tile contractors' licensing law, two examinations were held but no applicants were licensed.

An illustration of selective favoritism in the conduct of an examination may be drawn from electrical contracting in California. A wealthy person who was building an elaborate private residence there proposed to make electrical installations so complicated that he thought them beyond the ability of the ordinary electrical contractor. He therefore employed an electrical engineer who was a graduate of one of the best Eastern engineering schools to direct the work. Local building officials pointed out that the engineer was not licensed under the local requirement for licensing electrical contractors. Upon the engineer's offer to take an examination, they indicated that no special examination could be given and that the next regular examination would not be held for three months. Completion of the electrical work upon the residence was postponed in order to permit the engineer to take the cxamination. When the regular time arrived he took it but was reported to have failed. It is asserted that the reason for his failure was his inability to answer the question, How many inches from the floor should the electrical outlet be in a motion picture projection booth ? $^{2 \theta}$

II

In the light of the foregoing discussion it appears that contractor licensing laws serve purposes akin. to those which underlie a wide variety of private restraints of trade by building contractors. The requirement that contractors be licensed adds nothing to the play of motives and interests within the building industry. What it adds is an additional technique through which these motives and interests can be expressed. It is appropriate, therefore, to examine the licensing law as a technical device, in order to ascertain in what respect it enhances the opportunity to restrain trade.

The first of the law's contributions to the technique of restraint is the incorporation of substantive restrictions in the law itself. Reference has already been made to the fact that the licensing law as to tile contractors in North Carolina has been so framed as to exclude from the tile contracting field general contractors and subcontractors engaged primarily in other types of business; to the fact that the Pennsylvania plumbing law excludes persons who do not have a bona fide place of business and imposes a burden -of repeated re-registration upon persons who do business outside their own locality; and to the fact that the Illinois plumbing law appears to handicap contractors who operate in several different localities by requiring a licensed master plumber to be continuously in charge in each city.

to This example is based upon oral report by persons who asserted that they were personally familiar with the ficts. 
The second method of using the law for restrictive purposes consists in the establishment of high and discriminatory fees. Reference has already been made to a Pennsylvania city which for a time imposed upon outside contractors fees decidedly higher than those charged local contractors. In Illinois the plumbing law requires applicants for a master plumber's license to pay an application fee of \$100 and an annual renewal fee of $\$ 25$. This is obviously a substantial obstacle to journeymen plumbers who may wish to take plumbing contracts.

The third restrictive element consists in provision for relatively few examinations at infrequent dates. Reference has already been made to the difficulty which infrequent examination created in the case of an elaborate electrical installation in California. Under the North Carolina tile contractors' licensing law, only two examinations were held during the first year of the statute. The Illinois plumbing law provides that examinations shall be held at least four times each year and prohibits persons who fail from taking a re-examination until a full year has elapsed.

The fourth element which facilitates restraints is the opportunity for discrimination and favoritism inherent in an examining process where the examiners are in fluenced by the point of view of a private interest group. An illustration of discriminatory examination has been offered in the case of electrical contracting in California. The breadth of opportunity for such discrimination is apparent in various other cases. Under the North Carolina tile law, for example, as was announced at the tile contractors' annual convention, all members of the licensing board were members of the Tile and Mantel Contractors' Association of America. ${ }^{30}$ This throws light upon the fact that persons who were not regarded as orthodox tile contractors failed to qualify for licenses "either by reason of their lack of education or other qualifications to engage in such business." ${ }^{31}$ At the tile contractors' convention the question was.asked: "Did you say there were applications from general contractors?" It was answered, "Yes sir, and they were rejected."32

The Illinois plumbing law directs the State Department of Registration and Education to set up a board of examiners consisting of a master plumber who has been licensed for at least two years, a journeyman plumber who has been licensed for an equal length of time, and a third person designated by the Department. It also directs that in making the appointments from the trade due consideration shall be given to the recommendations of the Illinois Master Plumbers' Association and the Illinois Association of Journeymen Plumbers and Steam Fitters. ${ }^{33}$ The law provides that examination shall be conducted "by the Department with the aid and cooperation of the Board," and that the Department shall grant and deny licenses

${ }^{s 0}$ Proceedings, supra note 3 , at $8 \mathrm{r}$.

${ }^{21}$ Id. at 86.

${ }^{82}$ Id. at 87. However, in explaining that the qualifications of a tile contractor are entirely determined by the licensing board, the attorney who expounded the North Carolina law remarked, "Of course, the only purpose of the examination is to inquire into the fitness of the applicant as to his knowledge of tile contracting, and upon that basis alone. There are no politics, there is no unionism, or anything else that enters into the question of license except the personal qualifications of the man who is applying." Id. at 87-88.

as Il. Stat. ANN. (Jones, 1944) 5ro3-13. 
"upon the recommendation of the Board, respecting each applicant." 34 Thus, the statute itself opens the way for the official views of the contractors' association and the union to become the guides in granting licenses.

The Pennsylvania plumbing law also provides that examiners shall be drawn from the trade, though it does not give a similar recognition to the contractors' organization and the union. Mayors of cities are authorized to appoint boards of examiners consisting of a member of the Board of Health, a plumbing inspector, and two competent plumbers not connected with the city government. Examinations outside the cities are placed in the hands of boards of examiners appointed by the state Secretary of Health and consisting of master plumbers and journeymen plumbers of ten years' experience. The various examining boards are given the power to make "all reasonable rules, regulations, and examinations," subject to approval by city or state health authorities. ${ }^{35}$

Finally, the licensing statutes bring the coercive powers of the state to the support of the various restrictions involved in licensing. Some of the laws are enforced by fines and even by imprisonment. Under the Arizona law, for example, fines may range from $\$ 100$ to $\$ 500$ and imprisonment may be as long as six months. Under the Illinois plumbing law fines may range from $\$ 25$ to $\$ 500$, and imprisonment in the case of a first offense may be as much as six months and in case of a second offense, as much as a year. Under the Arizona law a construction contract with an unlicensed contractor is legally void. ${ }^{36}$ In North Carolina, as has already been pointed out, the penalties of the law may be applicable, not only to the unlicensed contractor, but also to persons who may be interpreted as accessory to his offense in that they have furnished him with tile.

Apart from the provisions of licensing statutes and the discriminatory features of their administration, the mere existence of a substantial number of local and state licensing requirements has the effect of assisting local contractors to exclude outsiders from local markets. Local laws typically do not recognize licenses issued in other localities or licenses issued under state laws. State laws typically give no recognition to local licenses or to licenses in other states. As licensing systems become more prevalent, a contractor who wishes to do business in various localities is likely to find himself required to take a series of examinations and pay a series of fees. The content of these various examinations will be as different as the varying ideas of examiners chosen largely from local members of the trade. At best such a multiplication of requirements must be burdensome. At, worst it can become insupportable. The inevitable tendency of the licensing system is to encourage each contractor to confine his operations to the locality in which he resides.

2t Id. at 5ro3.16-A, B.

${ }^{28}$ PA. Stat. Ann. (Purdon, Cum. Supp. 1944) tit. 53, 52533.

"Hunt v. Douglas Lumber Co., 41 Ariz. 276, i7 P. (2d) 815 (1933). At least the court so intimated, although the actual decision toss that a material man had 1 mechanies lien on a building built by an unlicensed contractor to whom the material man bad furnished materials for its construction in ignorance of the lack of license. 
III

The foregoing discussion has dealt with the impact of licensing upon the direct interests of contracting groups which are the advocates and beneficiaries of licensing laws. In addition, licensing has various indirect effects, both upon contracting groups and upon others. Some of the effects are doubtless not intended. Others, though perhaps intended, are not central in the strategy of contractors' associations. Nevertheless, these characteristics of licensing must be briefly described in an evaluation of the licensing system.

Licensing laws may be so drafted that they prevent a manufacturing establishment from maintaining its own buildings with its own work force without the intervention of a contractor. An aspiration to accomplish such a purpose was expressed in the tile contractors' convention during the discussion of the North Carolina law:

"Mr. PAGE: Have you in the state any big industrial plants that keep a maintenance gang, who go out and buy tile and set it with their own men?

"Mr. Carter: There would be a serious question of whether or not we could stop that job. Where you have a place and hire a regular man to work on your own premises and nothirg else, I would not want to question that.

"Mr. PAGE: We in Detroit have a great many of those plants-the Detroit-Edison will buy three or four thousand tile and set it with a maintenance gang. If we were in the state of North Carolina, could we stop that?

"MR. CARTER: I doubt it very seriously.""

In states in which the building trades are strongly unionized the licensing law for contractors may be so written as to dovetail with union requirements as to apprenticeship. In such cases the principle of apprenticeship may be extended to the contracting field, so that entry into the contracting trade is open in effect only to union members after a stated period of apprenticeship as journeymen. The Illinois plumbing law is an illustration of this device. It provides for the registration of master plumbers, journeymen plumbers, and apprentices. An applicant for registration as an apprentice must be at least sixteen years old and must submit an affdavit that he is to be immediately employed by a master plumber. An applicant for license as journeyman plumber must produce satisfactory evidence that he has been an apprentice for at least five years, or after a three-years' engineering course has been an apprentice for two years. An applicant for a license as master plumber, that is, as plumbing contractor, must show that he has been a licensed journeyman plumber for at least five years, or that he has graduated from a university engineering course and been employed by a licensed master plumber for at least two years as a licensed journeyman plumber, or that he has been a student in an engineering course for at least three years and has thereafter been employed by a master plumber as a licensed journeyman for at least three years. Licensed master plumbers are authorized to employ journeymen plumbers and apprentices, and licensed journeymen

${ }^{27}$ Proceedings, supra note 3 , at 88. 
plumbers and apprentices are authorized to engage in the plumbing business only as employees of licensed master plumbers. ${ }^{88}$

Thus the licensing laws for contractors and those for workmen are made to reenforce and support each other. A minimum period as a workman is required before one may become a contractor. If the union controls plumbing labor, plumbing contractors will inevitably have a union background. If a contractors' association controls the contracting group, those entering the trade as workmen will necessarily be-persons satisfactory to the association. A close working arrangement between organized labor and organized contractors is almost inevitable under such a law.

The significance of the type of relationship which has just been sketched is farreaching. Information is not available with which to discuss it adequately here. Briefly, however, it is probable that licensing systems often have the practical effect of strengthening the ability of contractors' associations and trade unions to enforce trade practices incorporated in their own private by-laws but not in the publicly enacted licensing laws.

An illustration will serve to indicate the possibilities, though it describes the relation betwen licensing and private rules in the case of a union rather than a group of contractors. It is drawn from a speech which I made in 1940 :

"The (building) code requires that electrical work be done by licensed electricians; and electrical work is so broadly interpreted that the city holds that even the connection of a welding machine cord to an outlet by plugging it in constitutes electrical work and must be done by a licensed electrician. The skill required for this operation is the same as that required to plug in a toaster at the breakfast table.

"Here is what actually happens. A builder who uses electrical welding must employ 2 licensed electrician to plug the cord in. Licensed electricians in that city are unionized. Under the rules of the union, plugging in a cord is not construction work but maintenance. Further, union rules provide that a maintenance electrician must not do construction work and must remain constantly on the job until its completion. Accordingly, the builder must hire a full-time maintenance electrician to be idle when not plugging in the cord. The welders in that town work an 8-hour day; the electrician, who must be present continuously during the eight hours, works a 6-hour day, with overtime pay thereafter. The consequence is that on one job it cost $\$ 1,000$ to get that plug plugged in by a licensed electrician."'

Obviously this illustration does not exhaust the possible complexities of such a case. If the union had a rule, as some local building unions do, that its members could work only for members of the contractors' association, neither the general contractor nor the welding contractor would be free to hire the union member without the intervention of an electrical contractor. In drawing in the contractors' association the union might also give effect to a contractors' by-law, common among such associations, by which member contractors are required to use bid depositories. Other similar possibilities come readily to mind. The extent to which they actually appear under systems for the licensing of building trades groups cannot be ascertained without extensive research.

\footnotetext{
"Irs. Stat. Ans. (Jones, 1944) \$5103.12, 103.15. $\quad$ "Edwards, srpra note 12, at 3.
} 
The effect of licensing laws may also be extended through the interconnection between such laws and local building codes. It is notorious that building codes include, sometimes by design and sometimes by inadvertence, a wide variety of provisions which handicap the introduction of new building materials and require the use of out-moded methods of construction. ${ }^{40}$

Often a builder can bring about the elimination of an absurd feature of a building code only by violating the code and thus procuring a judicial test of its propriety. Since builders are trying to operate for profit rather than as reformers of building codes, such efforts are undertaken far too seldom for the health of the building industry. Where the codes and the licensing laws have been interconnected, the opportunity to challenge a building code in this way may be substantially destroyed, because a builder who does so may jeopardize his whole future in the building industry within the territory over which the licensing authority has jurisdiction.

An illustration is to be found in the Illinois plumbing law. "Wilful violation. of any Plumbing Ordinance or by-laws of any city, town, or village or of any law of this state regulating the conduct of plumbing work" is ground upon which the state is required to revoke a master plumber's license. The statute contains provisions for review of revocations of licenses, but since revocation for violation of building codes is mandatory, this review would afford no relief. 41

Under the Arizona licensing law withdrawal of a license is discretionary with the Registrar of Contractors, rather than mandatory. However, the power to withdraw a license extends not only to wilful and deliberate disregard and violation of the building codes of the Federal government, the state, and any political subdivision of the state, but also to violation of the safety laws and labor laws of the Federal government and of the state. Thus exclusion from the building industry becomes a penalty available against wilful violators of a wide variety of statutes, the content of which has been rapidly expanded in recent years; and a deliberate challenge of the legality of any portion of these statutes is made peculiarly hazardous.

\section{IV}

In the foregoing discussion nothing has been said about the point which is often made by the advocates of contractor licensing that a license system is essential to protect the public against bad quality. A connection between licensing and quality tile licensing law described the tile work done by brick mason, plasterer, linoleum is often emphatically asserted. For example, the exponents of the North Carolina layer, general contractor, and self-employed workman, and concluded: "The result

\footnotetext{
${ }^{\circ}$ For example, a corporation which manufactures prefabricated houses has found it necessary to fight 2 continuous guerilla war against local building authorities to prevent the dimension requirements of local building codes from being used to outlaw structural members of its houses, even though with prefabrication methods these structural members will carry loads substantially greater than those which the dimension requirements of building codes are presumably designed to assure.

${ }^{11}$ IlI. Stat. ANN. (Jones, 1944) 5103.20.
} 
was inferior material, mostly seconds, bad workmanship and terrible looking jobs, which turned the owners and architects from clay tile to substitutes, such as glass, linoleum, rubber tile, asphalt tile, etc." As a result of licensing they said, "The general contractor has been relieved of many worries, among them the satisfaction of knowing he is going to get good material and competent workmanship. The buying public is also coming more and more to realize that tile work in North Carolina will be done right and when done right is an essential in most of the better constructions. The architect who has been constantly apologizing to the tile business for not specifying tile is now relieved of that duty as he now knows his tile work will be done as he desires it." 42

There is ground for considerable skepticism about the view that licensing laws are necessary as a guarantee for quality. In the first place, the granting of a license without examination to the entire body of established contractors obviously opens the way to continuance in business by a considerable number of persons whose work is of bad quality. In the second place, there is no obvious reason to believe that installations made by a general contractor or by an architect representing the owner will be skimped in quality in comparison with those made by a sub-contractor. When installations are made by established contractors whose main work lies in other building fields, the incentives to do good.work are identical with those which apply to the rest of the business of such contractors and to the business of contractors who specialize in the field which it is proposed to have licensed, that is, desire to maintain their business reputation and enlarge their clientele. It is not obvious that the differences between the various building fields are so sharp as to make it difficult to carry over skill as a contractor from one field into another. The only point at which it is plausible to suppose that licensing excludes a considerable amount of bad quality is where the licensing system is used to drive out the self-employed working man. Taking the quality argument at its full value with respect to this class of contractors, the question still remains how much of a price it may be desirable to pay in risk of inferior quality for the sake of retaining opportunities for a man to go into business for himself.

However, even this formulation of the case overemphasizes the importance of the quality argument. Bad quality in building may be divided into two categories. The first is a matter of appearance or durability not different in kind from bad quality in tailoring a suit of clothes. The second category is a matter of safety or sanitation, in which the interests of the community are involved as well as those of the householder. As to the first category, question arises whether there is any more reason to protect the ultimate consumer by licensing than there is in the many other occupations where quality varies and buyers are sometimes disappointed. In this connection it is noteworthy that the state of North Carolina licenses not only tile contractors but also photographers. If the principle of licensing is adopted in such cases, the eventual scope of the state's control over the right of entry into business is likely to be surprisingly large.

a Proceedings, supra note 3 , at 83,84 . 
As to the second category, provision for the protection of quality has already been made, apart from licensing, in the building regulations of most civilized communities. Requirements that plumbing and electrical installations be inspected are widespread, and they are usually accompanied by a requirement for the over-all inspection of new building structures. If the building inspector's job is adequately defined and adequately done, there is no reason to believe that a licensing law is needed to supplement it. In a jurisdiction where building inspection is slipshod, there is little reason to believe that the indirect and dubious provisions of a licensing law will accomplish the same purpose.

$\mathrm{V}$

Apart from whatever slight effect licensing laws may have upon the quality of construction, they obviously tend to reenforce those characteristics of the building industry which make its performance the least satisfactory of all our great industries. By any ordinary economic test the construction industry stands condemned. In a world in which most costs and prices are declining, construction costs and prices are maintained and driven higher. In a world in which mass production and consumption have become commonplace, the construction industry operates on a basis of petty production and has never succeeded in achieving mass consumption. The industry has so priced itself out of the market that we now take for granted the necessity of Federal subsidy in building residences for between one-fourth and one-half of our population. Construction methods are notoriously antiquated. Handicraft persists where machine methods are known. Small-scale purchase and sale and small-scale, localized operation continue where a larger-scale endeavor would clearly be economical. Restrictive practices and high price policies are more prevalent than in any other industrial field. Seasonal operation is greater than the weather requires. Idle resources are conspicuous even in good times and mass unemployment is a recurrent phenomenon.

A considerable number of factors contribute to the sickness of this industry, and there is no general agreement as to the exact relative importance of each. Nevertheless, it is widely agreed that the following are among the important factors:

x. No single enterprise is responsible for the construction and delivery of a complete building in the same way that one enterprise produces and delivers an automobile, a refrigerator, or a ship. Managerial responsibility and authority are diffused. In consequence every business man in the industry can truthfully say that he has little to gain by reducing his charges, because even a drastic reduction would not appreciably lower the cost of building and, therefore, would not enlarge his market. Equally important, no business man in any segment of the industry has authority broad enough to introduce new, more closely coordinated methods of construction which might greatly reduce costs.

2. The localized character of construction means that prefabrication is difficult, if not impossible, and that handicraft processes are bound to prevail, as they do wherever the market is too narrow for machine processes. 
3. The jurisdictional rules and trade practices of various groups in the construction industry, each anxious to protect its own position, have the aggregate effect of freezing the industry's technology, so that not even those changes are made which would be possible in a regime of diffused responsibility and localized markets. To attempt such changes is to become involved in bitter jurisdictional disputes which often cost more than would be saved by the new processes.

The contribution of contractor licensing is to consolidate these three characteristics. As in North Carolina, the licensing system forecloses attempts by general contractors or architects to extend the sphere of centralized direction of building construction. Its tendency to protect each locality against the competition of outsiders helps to maintain the localized production which is already characteristic of the industry. Its support for the jurisdictional rules and trade practices of particular contracting groups helps freeze building methods. Although the freezing is most conspicuous in construction activities, it extends also into a freezing of the channels for distribution of building materials, which diminishes the opportunity to reduce distribution costs. Thus contractor licensing laws are among the influences which tend to keep building costs high, which encourage policies of high prices and limited production, and which facilitate price-fixing. Thereby they help to limit the total market for construction services and construction materials. If this and other similar obstacles could be overcome, we might expect to see a larger volume of construction and also a more generous inclusion of comforts and luxuries in the houses which are now constructed. The immediate effect would be to increase employment in building and to diminish the industry's dependence upon public subsidy. A broader effect would be to enlarge the markets for building materials, particularly such materials as plumbing, electrical installations, tile, and similar commodities upon which the builder tends to skimp. A stimulus so broad as this could not fail to be felt as an influence toward prosperity throughout the entire economy. 